\title{
Implementasi Kebijakan Kepala Sekolah dalam Pembelajaran pada Masa Pandemi Covid 19 bagi Siswa Berkebutuhan Khusus di MTsN 10 Tanah Datar
}

\author{
Rika Maria ${ }^{1 凶}$, Johandri Taufan ${ }^{2}$, Nurhizrah Gistituati ${ }^{3}$, Sufyarma Marsidin $^{4}$ \\ ${ }^{1234}$ Administrasi Pendidikan, Universitas Negeri Padang, Indonesia \\ E-Mail: rikamaria26@vahoo.com ${ }^{\circledR 凶}$. iohandri.taufan@fip.unp.ac.id ${ }^{2}$, \\ gistituatinurhizrah@gmail.com ${ }^{3}$ sufyarma@fip.unp.ac.id ${ }^{4}$
}

\section{INFORMASI ARTIKEL}

Terkirim 28-Mei-2021

Revisi 30-Mei-2021

Diterima 02-Juni-2021

\section{Kata kunci:}

Kebijakan Kepala Sekolah;

Anak Berkebutuhan Khusus;

Covid 19.

\begin{abstract}
ABSTRAK
Penelitian ini bertujuan untuk melihat bagaimana implementasi terkait kebijakan sekolah dalam pembelajaran dimasa covid 19 bagi siswa berkebutuhan khusus. Penelitian mendeskripsikan dampak dari kebijakan yang di berikan sekolah bagi siswa-siswa berkebutuhan khusus saat pembelajaran daring, serta permasalahan apa yang ditimbulkan dari kebijakan tersebut dan solusi apa yang diberikan dalam mengatasi permasalahan tersebut. Adapun metodologi dalam penelitian yang digunakan menggunakan pendekatan kualitatif dengan jenis penelitian studi kasus. Sumber data diperoleh melalui wawancara dan dokumentasi. Hasil dari penelitian ini menunjukkan bahwa kebijakan-kebijakan yang diberikan adalah menerapkan pembelajaran secara tatap muka melalui pembatasan jumlah siswa sesuai dengan protokol kesehatan. Pembelajaran dilakukan pershift dengan 3 hari tatap muka. 3 hari secara daring. Kendala dalam penerapan kebijakan ini diantaranya sulitnya jaringan saat pembelajaran secara daring dilakukan. Solusi dalam kebijakan ini yaitu adanya kunjungan rumah yang dilakukan guru, selain itu sekolah juga memberikan kemudahan dengan memperbolehkan orang tua untuk mengantarkan tugas siswa ke sekolah.
\end{abstract}

\section{Pendahuluan}

Pendidikan merupakan hal yang sangat strategis dalam menentukan arah kemajuan suatu bangsa. Dengan adanya pendidikan yang bermutu dan berkualitas, penyiapan sumber daya manusia akan menjadi terarah dan baik, sesuai dengan kualitas yang dikehendaki untuk mendorong suatu kemajuan bangsa. Dengan pendidikan tersebut generasi muda menjadi terarah masa depan dan kehidupannya. Diantara tempat memperoleh pendidikan adalah sekolah, dimana sekolah merupakan tempat proses memperoleh pembelajaran.

Pembelajaran merupakan proses internalisasi ilmu pengetahuan ke dalam skemata pelajar. Pada proses ini terdapat aktivitas siswa sebagai pelajar dan terdapat aktivitas guru sebagai pembelajar. Pembelajaran dilakukan dengan tahap perencanaan, pelaksanaan, dan evaluasi oleh pendidik kemudian diaplikasikan melalui pertemuan klasikal dengan didukung media, alat, dan bahan yang sesuai. Tetapi saat ini hampir di sebagaian Negara mengamali 
perubahan dalam pelaksanaannya karena dampak dari Covid-19.

Covid-19 atau dikenal dengan istilah coronavirus diseases sendiri merupakan penyakit jenis baru yang belum pernah diidentifikasi sebelumnya pada manusia. Tanda dan gelaja umum infeksi Covid-19 antara lain gejala gangguan pernapasan akut seperti demam, batuk, dan sesak napas. Masa inkubasi rata-rata 5- 6 hari dengan masa inkubasi terpanjang 14 hari. Pada tanggal 30 Januari 2020 WHO telah menetapkan sebagai kedaruratan kesehatan masyarakat yang meresahkan dunia. diri Indonesia sendiri merupakan Negara yang saat ini mengalami dampak dari Covid-19 ini hampir disemua sektor kehidupan. Dampak dari Covid-19 terjadi diberbagai bidang seperti sosial, ekonomi, pariwisata dan pendidikan. Surat Edaran (SE) yang dikeluarkan pemerintah pada 18 Maret 2020 segala kegiatan didalam dan diluar ruangan di semua sektor sementara waktu ditunda demi mengurangi penyebaran corona terutama pada bidang pendidikan.

Oleh sebab itu Menteri Pendidikan dan Kebudayaan Republik Indonesia mengeluarkan Surat Edaran Nomor 4 Tahun 2020 Tentang Pelaksanaan Kebijakan Pendidikan Dalam Masa Darurat Penyebaran COVID, dalam Surat Edaran tersebut dijelaskan bahwa proses belajar dilaksanakan di rumah melalui pembelajaran daring/jarak jauh dilaksanakan untuk memberikan pengalaman belajar yang bermakna bagi siswa. Tentunya dengan adanya kebijakan tersebut, sekolah harus memiliki kesiapan dalam menerapkan kebijakan tersebut. Selanjutnya pada Surat edaran No 15 Tahun 2020 oleh Kementerian Pendidikan dan Kebudayaan Republik Indonesia tentang pedoman penyelenggaraan belajar dari rumah dalam masa darurat bencana Covid-19 menjelaskan bahwa: (1) pengaturan mekanisme antar jemput peserta didik oleh satuan pendidikan, (2) sarana dan prasarana dilakukan sterilisasi secara rutin minimal dua kali, (3) pemantauan secara rutin kondisi warga sekolah oleh pihak sekolah, (4) menyediakan dan wajib memberikan tempat cuci tangan dengan sabun, (5) menerapkan protokol kesehatan seperti jaga jarak dan etika batuk dan bersin, dan (6) pembuatan narahubung oleh pihak sekolah berkaitan dengan keamanan dan keselamatan di lingkungan sekolah. Diantaranya adalah kepala sekolah sebagai pengambil kebijakan yang akan memberlakukan kebijakan tersebut sesuai dengan keadaan sekolahnya. Pendidikan jarak jauh menjadi alternatif terbaik yang bisa dilaksanakan supaya proses belajar mengajar dapat tetap berlangsung meskipun siswa berada di rumah masing-masing. Pembelajaran jarak jauh atau daring merupakan pembelajaran yang dijalankan dengan mengaplikasikan internet sebagai tempat mendapatkan ilmu pengetahuan (Hermanto et al., 2020)

Pembelajaran jarak jauh merupakan kebijakan yang saat ini telah diterapkan di sekolah, dimana pembelajaran jarak jauh yang dimaksud adalah pembelajaran secara daring. Menurut Isman pembelajaran daring merupakan pemanfaatan jaringan internet dalam proses pembelajaran. Pembelajaran daring adalah bentuk pembelajaran yang mampu menjadikan siswa mandiri tidak bergantung pada orang lain (Syarifudin, 2020). Dengan adanya pembelajaran daring siswa dapat memiliki keleluasaan waktu belajar, dapat belajar kapanpun dan dimanapun. Siswa dapat berinteraksi dengan guru menggunakan beberapa aplikasi seperti classroom, video converence, telepon atau live chat, zoom maupun melalui whatsapp group. Pembelajaran ini 
merupakan inovasi pendidikan untuk menjawab tantangan akan ketersediaan sumber belajar yang variatif. Selanjutnya keberhasilan dari suatu model ataupun media pembelajaran tergantung dari karakteristik dan kemampuan peserta didiknya. Sebagai mana yang diungkapkan oleh Nakayama bahwa dari semua literatur dalam elearning mengindikasikan bahwa tidak semua peserta didik akan sukses dalam pembelajaran secara online (Dewi, 2020). Ini dikarenakan faktor lingkungan belajar dan karakteristik dan kemampuan peserta didik terutama peserta didik berkebutuhan khusus.

Peserta didik berkebutuhan khusus sendiri merupakan peserta didik yang memiliki hambatan baik dari segi intelektual, emosi, prilaku, fisik/motorik sehingga dalam proses pembelajarannya memerlukan layanan khusus yang sesuai dengan kemampuannya. Peserta didik berkebutuhan khusus merupakan bagian dari peserta didik pada umumnya, mereka memiliki kesempatan yang sama dalam pendidikan dan berhak untuk mengikuti kegiatan belajar di semua satuan dan jenjang persekolahan. Tempat bersekolah mereka tidak hanya di sekolah khusus, tetapi juga di sekolah umum terutama yang terdekat dengan tempat tinggalnya.

MTsN 10 Tanah Datar merupakan sekolah yang menerima peserta didik berkebutuhan khusus yang saat ini yang mana dalam pembelajaran dimasa pandemi Covid 19 ini juga terkena dampak dari kebijakan pembelajaran jarak jauh ini. Kepala sekolah selaku pengambil kebijakan perlu melihat kemampuan dari peserta didik terutama peserta didik berkebutuhan khusus agar kebijakan yang di terapkan tidak membuat peserta didik berkebutuhan khusus mengalami kesulitan dalam menerapkan pembelajaran sesuai kebijakan yang dibuat oleh kepala sekolah.

Peserta didik berkebutuhan khusus yang berada di MTsN 10 Tanah Datar sebagian merupakan peserta didik yang mengalami hambatan dalam belajar seperti kesulitan belajar dan juga terdapat peserta didik yang mengalami lamban belajar, sehingga dalam pembelajarannya sangat membutuhankan strategi dan metode yang dapat membantu mereka dalam memahami pembelajaran. Dengan adanya pandemic ini, tentunya kepala sekolah perlu menerapkan kebijakan yang tidak merugikan peserta didik, terutama mereka peserta didik berkebutuhan khusus yang sangat membutuhkan interaksi langsung bersama guru.

Dari uraian di atas tujuan dari penelitin ini adalah perlu dilihat dan diteliti seperti apa kebijakan-kebijakan yang dibuat oleh kepala sekolah terkait pembelajaran di masa pandemi Covid 19 ini?. Bagaimana implementasi dari kebijakan tersebut?, dan adakah kendala dalam implementasi kebijakan yang dibuat?, serta solusi apa yang diterapkan sekolah dalam mengatasi kendala tersebut?

\section{Metode}

Metodologi pada penelitian ini menggunakan pendekatan kualitatif dengan desain deskriptif, dimana desain deskriptif tersebut untuk memberikan gambaran tentang implementasi kebijakan yang dibuat kepala sekolah untuk diterapkan bagi peserta didik berkebutuhan khusus selama masa pandemic covid 19. Populasi penelitian adalah guru, peserta didik berkebutuhan khusus dan orang tua dari peserta didik berkebutuhan khusus. Teknik pengumpulan sampel yang digunakan yaitu sample random sampling, yang berarti masing-masing anggota populasi 
memiliki peluang dan kesempatan yang sama untuk menjadi sampel penelitian. Teknik pengumpulan data dilakukan dengan wawancara secara daring. Adapun teknik wawancara yang digunakan termasuk dalam teknik wawancara tidak terstruktur yang mana hanya memuat tentang implementasi kebijakan kepala sekolah. Data yang diperoleh dari wawancara dan angket tersebut, kemudian dianalisis menggunakan konsep Miles dan Huberman melalui reduction, data display dan conclusion (Milles \& Huberman, 2013).

\section{Hasil Penelitian dan Pembahasan}

Di masa pandemic ini dunia pendidikan makin hari makin menunjukan ketidak stabilan dalam proses pembelajaran secara tatap muka. sementara dalam melakukan pelayanan pendidikan yang baik terutama kepada siswa didik berkebutuhan khusus harus didukung dengan situasi yang baik dan didukung oleh sarana pembelajaran yang memadai. Sementara itu keberhasilan pembelajaran yang baik bukan hanya tanggung jawab seorang guru yang menjalankan aktivitas belajar mengajar tetapi juga ditentukan oleh komitmen bersama kepala sekolah dan warga sekolah lainnya dalam penentuan kebijakan yang akan diimplementasikan (Hermanto et al., 2020). Kepala sekolah merupakan bagian terpenting yang memiliki peranan besar dalam menentukan kemajuan sekolah untuk itu peran kepala sekolah dalam penentuan kebijakan menjadi keharusan di situasi seperti ini.

Kebijakan belajar dari rumah merupakan kebijakan yang dikeluarkan oleh Kementerian Pendidikan dan Kebudayaan Republik Indonesia melalui SE nomor 4 tahun 2020 tentang pelaksanaan pendidikan masa darurat penyebaran Corona Virus Desease 2019 (Covid-19). Dengan adanya kebijakan tersebutlah kemudian berdampak proses pembelajaran yang ada di sekolah, bukan hanya bagi guru tetapi sangat berdampak bagi peserta didik, maupun orang tua atau keluarga peserta didik (Purwanto \& dkk, 2020).

Kebijakan yang dikeluarkan tersebut sebagai upaya untuk menyelamatkan peserta didik dari bahaya virus tetapi justru pula akan menimbulkan beberapa dampak khususnya pada peserta didik, guru, dan orang tua. Peserta didik sendiri akan merasa terpaksa belajar dari rumah yang sebenarnya tidak memiliki fasilitas yang memadai untuk hal tersebut, dengan begitu maka proses pembelajaran akan terhambat yang seharusnya sebelum dimulainya pembelajaran tersebut fasilitas pendukung harus tersedia lebih dahulu. Kemudian selanjutnya terletak pada proses adaptasi pembelajaran, peserta didik yang tadinya cenderung berinteraksi langsung dalam pembelajaran akan memerlukan berbagai macam adaptasi belajar serta memahami pembelajaran yang di modelkan dalam jaringan, sehingga kebijakan yang diberikan bisa saja menimbulkan mandeknya pemahaman peserta didik terhadap pembelajaran. Mengigat bahwa perubahan ke pembelajaran online secara 'tidak langsung berpengaruh terhadap daya serap peserta didik (Dewi dalam Saleh, 2020).

Hampir semua sekolah telah menerapkan pembelajaran jarak jauh atau yang biasa dikenal dengan daring dalam proses pembelajarannya, tetapi bagi sekolah MTsN 10 Tanah Datar memiliki kebijakan yang berbeda dalam proses pelaksanaan pembelajaran di sekolahnya. Hasil 
penelitian menunjukkan bahwa kebijakan yang diterapkan oleh kepala sekolah dalam masa pandemic ini adalah dengan menerapkan pembelajaran secara bergantian atau yang dikenal dengan pershift. Dalam proses pelaksanaannya, pembelajaran ini dilakukan dengan jumlah siswa yang berbeda disetiap harinya, karena model yang digunakan adalah 3 hari tatap muka dan 3 hari secara daring. Model pershift ini juga berlaku kepada peserta didik berkebutuhan khusus, yang mana bagi peserta didik berkebutahan khusus untuk pembelajaran secara tatap muka sangat diperlukan dalam perkembangan akademiknya.

Berdasarkan hasil wawancara, kebijakan ini diambil oleh kepala sekolah karena melihat bahwasanya sekolah memiliki peserta didik berkebutuhan khusus yang memang sangat membutuhkan pembelajaran secara tatap muka dalam layanan pendidikannya. Akan sulit jika perserta didik berkebutuhan khusus yang mengalami hambatan berupa kesulitan belajar baik itu kesulitan belajar membaca, berhitung maupun menulis diberikan pembelajaran secara online terus menerus. Dampak yang timbul jika pelaksanaan pembelajaran dilakukan secara daring setiap harinya, maka perkembangan akademik siswa tidak akan meningkat. Selanjutnya dengan menggunakan model pembelajaran secara pershift ini juga memudahkan orang tua dalam ikut serta keterlibatan proses pendidikan anaknya, karena memang tidak semua orang tua dari peserta didik berkebutuhan khusus tersebut memiliki ekonomi yang baik. Kebijakan ini diterapkan kepala sekolah agar nantinya jika peserta didik berkebutuhan khusus mengalami kendala dalam pengumpulan atau pengerjaan tugasnya, sekolah mempersilahkan orang tua untuk mengantarkan tugas dari anaknya. Selanjutnya kebijakan yang diterapkan oleh kepala sekolah bagi pembelajaran secara daring adalah dengan menggunakan platform-platform yang telah disediakan dalam mendukung proses pembelajaran secara daring. Platform yang digunakan diantaranya menggunakan whatsapp, zoom ataupun google meat. Diharapkan dengan adanya pembelajaran menggunakan platform yang telah disediakan dapat tetap membantu peserta didik dalam proses pembelajarannya sehingga materi yang diberikan dapat dipelajari oleh peserta didik.

Adanya kebijakan yang diterapkan tentunya juga akan ada permasalahan atau kendala yang muncul. Terutama kendala pada saat pelakasanaan pembelajaran secara online. Dapat kita ketahui masalah terbesar dalam pelaksanaan pembelajaran secara daring adalah sinyal internet. Bagi sekolah dan rumah yang berada ditengah kota mungkin saja permasalahan ini tidak begitu besar, tetapi bagi sebagian sekolah dan rumah peserta didik yang berada pada wilayah yang sangat lemah sinyal, tentunya pembelajaran secara jauh atau secara daring ini tidaklah optimal. Terlebih ketika pelaksanaan pembelajaran yang semula secara tatap muka berubah menjadi pembelajaran secara daring. Guru sangat berperan besar dalam menyiapkan materi pembelajaran tersebut. Ketidaksiapan guru dan peserta didik terhadap pembelajaran daring juga menjadi masalah. Perpindahan sistem belajar konvensional ke sistem daring secara tiba-tiba (karena pandemi covid-19) tanpa persiapan yang matang. Akhirnya, sejumlah guru tidak mampu mengikuti perubahan dengan pembelajaran berbasis teknologi dan informasi. Padahal sebuah keniscayaan guru itu memanfaatkan teknologi untuk mendukung pembelajarannya, lebih-lebih di 
masa pandemi Covid-19. Mau tidak mau, siap tidak siap, semua ini harus tetap dilaksanakan agar proses pembelajaran dapat berjalan dan terpenuhinya hak peserta didik dalam memperoleh pendidikan walaupun dalam kondisi pandemi Covid-19 (Asmuni, 2020). Oleh sebab itu kemampuan mengorganisasikan materi terdiri dari dua tahap, yaitu memilih materi pembelajaran dan menyusun materi pembelajaran. Ketika pembelajaran berlangsung secara tatap muka, guru sudah terbiasa untuk melakukan pengorganisasian pembelajaran. Namun, hal yang menjadi kendala, ketika pembelajaran berlangsung secara daring. Guru harus memilih materi pembelajaran dengan ekstra agar tidak terjadi miskonsepsi antara guru dan walimurid atau siswa ketika mempelajari materi. Disisi lain, guru juga harus melihat ketercapaian kompetensi dasar yang harus dikuasai siswa. Sehingga pembuatan materi ketika pembelajaran dilakukan secara daring harus dilakukan dengan maksimal.(Mulyasa, 2013).

Solusi yang ditawarkan oleh kepala sekolah dalam penerapan kebijakan pembelajaran secara daring ini yaitu kepala sekolah memberikan kebijakan kepada orang tua yang mengalami kendala dalam mengumpulkan tugas peserta didiknya terutama peserta didik berkebutuhan khusus, orang tua dapat menghantarkan tugas tersebut kesekolah. Ini dilakukan agar meskipun peserta didik yang tidak memiliki smartphone atau gadget lainnya juga dapat ikut melakasanakan proses pembelajaran meskipun dilakukan secara daring. Dengan adanya kebijakan tersebut, lebih memungkinkan peserta didik lebih aktif dalam proses pembelajarannya. Selain itu kebijakan yang diberikan kepala sekolah dalam mengatasi permasalahan pembelajaran secara daring terutama yang memiliki permasalahan sinyal adalah dengan memberikan tugas kepada guru untuk melaksanakan kunjungan rumah. Dengan adanya kebijakan ini, bukan hanya peserta didik pada umumnya saja yang terbantu, tetapi bagi peserta didik berkebutuhan khusus sangatlah berarti dalam proses perkembangan kemampuan akademiknya. Kebijakan-kebijakan yang diberikan kepala sekolah mulai dari membuat system pershift atau pengaturan waktu sekolah, sampai mengadakan guru kunjung kerumah, sangat membantu perserta didik berkebutuhan khusus dalam proses pembelajarannya. Yang tidak kalah lebih penting adalah kebijakan yang diberikan kepala sekolah kepada guru adalah dengan memberikan pelatihan-pelatihan dalam menguasai pembelajaran secara daring, agar guru-guru tidak gagap teknologi dalam melaksanakan pembelajaran secara daring ini.

\section{Kesimpulan}

Pelaksanaan pembelajaran daring yang merupakan pembelajaran jarak jauh di masa pandemi covid-19 memiliki beragam problematika terutama bagi peserta didik berkebutuhan khusus. Perlu adanya kebijakan yang mengatur terkait proses pelakasanaan pembelajaran bagi peserta didik berkebutuhan khusus. Kebijakan-kebijakan yang diterapkan kepala sekolah MTsN 10 Tanah Datar dalam pembelajaran dimasa pandemic ini diantaranya adalah memberlakukan system pengaturan waktu atau pershift bagi peserta didik, dimana peserta didik melakukan pembelajaran tatap muka selama 3 hari dan pembelajaran secara daring selama 3 hari. Selain itu untuk mendukung proses pembelajaran daring yang baik dan efektif, kepala sekolah memberikan 
pelatihan kepada guru-guru agar dapat mengusasi teknologi pembelajaran agar dapat memberikan pelayanan yang efektif bagi peserta didik.

Kendala-kendala yang muncul saat proses pembelajaran secara daring diantaranya permasalahan sinyal internet yang kurang baik, diberikan kebijakan bagi orang tua untuk diperbolehkan mengambil tugas dan mengumpulkan tugas dengan diantar ke sekolah. Selain itu untuk membantu agar proses pembelajaran jarak jauh berjalan optimal, kepala sekolah membuat kebijakan agar diadakannya guru kunjung. Hal ini sangat baik bagi peserta didik berkebutuhan khusus, Karena dengan adanya guru kunjung dapat memudahkan peserta didik berkebutuhan khusus dalam memahami materi pembelaran.

\section{Daftar Rujukan}

Asmuni, A. (2020). Problematika Pembelajaran Daring di Masa Pandemi Covid-19 dan Solusi Pemecahannya. Jurnal Paedagogy, 281-288. https://doi.org/10.33394/jp.v7i4.2941

Dewi, W. A. F. (2020). Dampak COVID-19 terhadap Implementasi Pembelajaran Daring di Sekolah Dasar. Edukatif: Jurnal Ilmu Pendidikan, 2(1), 55-61. https://doi.org/10.31004/edukatif.v2i1.89

Hermanto, Arita Marini, \& Mohamad Syarif Sumantri. (2020). Studi Kebijakan Kepala Sekolah Dalam Pembelajaran Daring Bagi Siswa Sekolah Dasar di Era New Normal Pada Masa Pandemik Covid-19. Jurnal Basicedu, 5(3), 524-532. https://doi.org/https://doi.org/10.31004/basicedu.v5i3.936 ISSN

Milles, \& Huberman. (2013). Qualitative Data Analysis: A Methods Sourcebook. Los Angeles: SAGE Publications.

Mulyasa. (2013). Pengembangan dan Implementasi Kurikulum 2013. PT Remaja Rosdakarya.

Purwanto, A., \& dkk. (2020). Studi Eksploratif Dampak Pandemi COVID-19 Terhadap Proses Pembelajaran Online di Sekolah Dasar. EduPsyCouns Journal: Journal of Education, Psychology, and Counseling. Wekke.

Saleh, A. M. (2020). Problematika Kebijakan Pendidikan Di Tengah Pandemi Dan Dampaknya Terhadap Proses Pembelajaran Di Indonesia. Jurnal Pendidikan, 2(2), 24-24.

Syarifudin, A. S. (2020). Impelementasi Pembelajaran Daring Untuk Meningkatkan Mutu Pendidikan Sebagai Dampak Diterapkannya Social Distancing. Jurnal Pendidikan Bahasa Dan Sastra Indonesia Metalingua, 5(1), 31-34. https://doi.org/10.21107/metalingua.v5i1.7072 